\title{
Library Service Program Evaluation Web-Based Online Public Access Catalog (OPAC) at Polytechnic of Health Ministry of Health Jakarta III
}

\author{
Haryanto $^{1}$; Indra Supradewi ${ }^{2} ;$ Hot Rohaida ${ }^{1}$ \\ ${ }^{1}$ Library Ministry of Health Polytechnics Jakarta III, Indonesia \\ ${ }^{2}$ Department of Midwifery, Ministry of Health Polytechnics Jakarta III, Indonesia \\ http://dx.doi.org/10.18415/ijmmu.v9i2.3423
}

\begin{abstract}
This research is about evaluating the Online Public Access Catalog (OPAC) web service program at Poltekkes Kemenkes Jakarta III. The implementation of the OPAC web has been implemented since 2007 to provide easy, fast, and accurate information retrieval system services for users. The problem is how are the achievement, benefit, and impact of the OPAC service program? Evaluative qualitative research method using the Context Input Process Product (CIPP) model. The number of informants is 15 people consisting of elements of leadership, lecturers, students, and education staff. Data collection with interviews, observations, and document studies. Data analysis by triangulation is linking the three sources of information with a careful test of the validity of the data. The results of the study are as follows; 1) evaluation of context: $70 \%$ is achieved with a match between policies and leadership support in developing ICT-based library service programs. Meanwhile, $30 \%$ has not been achieved, because there is no written policy. 2) evaluation of inputs; includes the availability of collections, facilities, infrastructure, and library human resources. Achievement of $80 \%$ with adequate collections and adequate computer facilities. While the shortage of $20 \%$ is a shortage of librarians who have not met the National Library Standards. 3) the evaluation process can run quite well, the users do not experience problems, which means that $100 \%$ is achieved. 4) Product evaluation was achieved quite well $100 \%$. Users feel the benefits of the OPAC web service in disbursing information to optimize the utilization of the Poltekkes Library of the Ministry of Health Jakarta III.
\end{abstract}

Keywords: OPAC Evaluation; Library Services

\section{Introduction}

Libraries as a vehicle for lifelong learning develop the potential of the community to become human beings who believe and are devoted to God Almighty, have noble character, are healthy, knowledgeable, capable, creative, independent, and become democratic citizens and are responsible for supporting the implementation of national education. No. 43 of 2007 concerning Libraries). The library operation is based on the principles of lifelong learning, democracy, justice, professionalism, openness, measurability, and partnership. So that the library can function as a vehicle for education, research, preservation, information, and recreation to increase the intelligence and empowerment of the nation. 
Organizing a library is felt to be very important for the wider community, especially for the academic community of a university. Easy, cheap, and fast library services are a dream for every user. The existence of the library will be felt more meaningful, if the users feel comfortable and useful in meeting the information needs needed. Therefore, libraries need efforts to improve service programs in line with the development of information and communication technology (ICT). One of the information services programs that need to be implemented is the application of the Online Public Access Catalogue (OPAC) web.

In various university libraries, the application of OPAC is a necessity that must be implemented. Because the system can integrate various databases of data collections, members and librarian. Readers will find it easier to find the title or author of the book they need through a computer with OPAC installed or their gadget. Libraries that have been installed with OPAC will be accessible wherever they are, but the borrowing process must still come to the library. There are quite several benefits with the installation of OPAC, so if the library does not pay attention to the program, the librarian is difficult to control and control in an integrated library service program.

Since 2007 the Polytechnic of Health Ministry Of Health Jakarta III (Poltekkes Kemenkes Jakarta) Library has been using OPAC, but its utilization is still low (40\%). This is indicated by the number of lecturers and students who still do not use OPAC facilities in searching for information. This OPAC program has been socialized to lecturers and students in every activity such as Introduction to Campus Life for New Students (PKKMB) and literacy guidance for students who will complete their final project, but it is felt that the utilization of the OPAC facilities is not optimal. Based on the description above, it is important to evaluate the OPAC web-based library service program as a material for policy considerations and the development of library service models in the future in line with the changing vision of the Poltekkes Kemenkes Jakarta III which wants to be a "Higher Health Education Institution that excels in Health Technology". ASEAN Level" in 2028

\section{Research Methods}

The evaluation research approach used is a qualitative approach. The purpose of qualitative research is to develop an understanding of individuals and events by considering the relevant context. Test the validity of the data by triangulation of sources and methods, namely: the collected data is validated internally, externally checked. The methods used are various types of triangulation methods, namely source triangulation, method triangulation, and investigator triangulation, and theoretical triangulation.

\section{Research Result}

Context Component, the results of the information context component include support for information technology-based library development policies. The director's policy support began with the dissemination of Information Technology-based Modern Library Development Poltekkes Jakarta III which was held on December 5, 2005, in the Hall of the Persabatan Nursing Study Program. Furthermore, in 2007 the Poltekkes Depkes Jakarta III Library conducted a library automation program with an application called LISA (Library Information System Automation). The LISA application is based on a web-based online public access catalog (OPAC) as a means of locating collection information for users.

The following is the result of an interview with the Deputy Director of Health Poltekkes, Ministry of Health, Jakarta III, as the Director's representative, saying that "The role of the Jakarta III Health Polytechnic library is very supportive and has an important role in achieving the vision of the institution (BM, 7 August 2021). The vision and mission of the Poltekkes Kemenkes Jakarta III is "To become a Superior Higher Education Institution Based on Health Science and Technology at the ASEAN level in 2028" as stated in the Strategic Plan of the Health Polytechnic of the Ministry of Health Jakarta III 20192023. For the stages and achievements of activities, the objectives, and strategies of which are related to 
the library is the fulfillment of the need for quality learning facilities and infrastructure by developing a digital and integrated library service system. M Ichwan stated that the library has been supported in the development of ICT and has also had a role in supporting the realization of the vision and mission, especially supporting the tri dharma of higher education. However, until now there has not been a written policy regarding the application of a web-based online public access catalog library application. Although the funding has received budget support in providing applications and training for library staff competence in providing computerized systems. Input Component, the results of the input component information include the availability of collections, infrastructure, and library human resources.

\section{Collection Availability}

The Poltekkes Kemenkes Jakarta III Library has a complete collection in terms of various subjects and adequate numbers to support the learning and research process. Based on the statistical report of the Poltekkes Kemenkes Jakarta III Library on November 1, 2021, the number of collections is 9,623 books with a total of 21,331 copies. The various types of collections include teaching materials, reference collections, serial publications, government publications, non-print collections, and reading materials for recreation such as literature. The number of collections has been processed and entered in the library application so that it is easy to browse through the OPAC web. The rack arrangement system is based on the DDC classification and can be retrieved directly by the user with an open service system. To develop collections, lecturers and students can participate in providing input through a survey of user needs or make suggestions directly to the librarian. So that the available collections are right on target according to the needs of users. The following are the results of interviews between researchers and informants: What is the role of the Jakarta Ministry of Health Poltekkes library in supporting the tri dharma of higher education? The following are informants from lecturers and students, namely.

"Yes, libraries really support education, research, and community service for lecturers" (SR, 7 August 2021).

"Libraries play a very important role in learning, research, and community service activities. Books, journals, videos, and videos are very helpful for lecturers and students in finding learning resources" (WF, August 8, 2021).

"Very supportive in the implementation of the Tri Dharma of Higher Education, especially during the accreditation of the physiotherapy profession study program. Often lecturers and students take advantage of the library, both its collections and suggestions and infrastructure" (GS, 8 August 2021).

"Libraries are very helpful in obtaining research materials, journal references and as a place to enter journals for readers" (MC, August 8, 2021)

"Can help learning resources, do the assignments of lecturers and do assignments in the library". (FA, 9 August 2021).

"Yes, I think the Poltekkes Jakarta III library is very useful and a source for seeking knowledge and learning subjects that are not in textbooks". (DA, August 9, 2021).

"Has a role in learning and completing the final project (thesis), especially in accessing national and international journals" (FM, 9 August 2021). From these data, the library has a collection that can support learning, research and community service programs for lecturers and students. 


\section{Availability of Facilities and Infrastructure}

The results of the document review and observation that the Poltekkes Library of the Ministry of Health Jakarta III already has the facilities and infrastructure to support information service programs, especially in OPAC services. Two computers are provided specifically for OPAC services for users. The two computer units are placed in the room before entering the collection so that users can browse through the available computers. In addition, 10 computers are provided for internet service, so that it is sufficient for information retrieval for users. The internet network provided through the hotspot is quite good, 500 MB is available in the library room. Currently, lecturers and students can access OPAC through their respective androids or laptops by utilizing the internet network. However, based on the researcher's observation that the number of computers needs to be added and upgraded so that the speed of browsing is more effective. Related to the support for the provision of infrastructure for optimizing library services, the following interview results can be obtained. "What is the policy of the director in supporting the optimal implementation of library services?".

"The directors and management are very supportive regarding the progress of the library by providing the facilities/budget needed for library development in accordance with the priority scale" (BM, August 7, 2021). Thus, the provision of facilities and infrastructure needs to be improved, but still refers to the priority scale of needs.

\section{Availability of Library Human Resources}

The number of library staff or human resources currently consists of 3 (three) librarians with a background in library science education and 4 (four) administrative staff with a high school education background. The number of librarians is still lacking, delivered by M. Ichwan referring to the National Library Standard (SNP). For the organization and management of a library with more than 2,500 students, five librarians are needed and for every additional 500 students, 1 librarian is needed. For the addition of librarians has been proposed by the Head of the Library Unit through a letter requesting additional personnel, but so far it has not been implemented.

Process Components, the results of the document review show that the process components have been running quite well. The Poltekkes Kemenkes Jakarta III Library has implemented the LISA (Library Information System - Automation) application since 2007. The LISA application is a web-based library information system to support library automation activities. This application is equipped with complete and integrated features in managing collections, library members, and admin managers. This makes it easier for borrowing circulation transactions and information retrieval for users. The Online Public Access Catalog feature, abbreviated as OPAC, is a search tool intended for users. OPAC in LISA consists of a simple search, specific search with image display, title, author. Furthermore, for specific information, it contains additional details of other information such as calling number, ISBN/ISSN, language, publisher, year of publication. The Poltekkes Kemenkes Jakarta III Library provides 2 special computers for OPAC services for visitors. For how to use the OPAC, students and lecturers are given user guidance both individually and in groups. For new students, user guidance is carried out during PKKMB (Introduction to New Student Campus Life). The Poltekkes Kemenkes Jakarta III Library also provides Library Management Procedures and Library Service Work Instructions. The work instructions for library services include explaining how users can independently search for books they want to borrow through the OPAC. The following are the results of interviews with informants about library visits and the use of OPAC by lecturers and students:

"How many times do you visit the Jakarta III Poltekkes library in a year?"

"More than 20 times" (BM, 7 August 2021).

"12 live and $10 x$ online". (SR, August 7, 2021). 
"24 times more". (WF, August 8, 2021).

"10 times more". (GS, August 8, 2021).

"7 times more". (MC, August 8, 2021).

" $6 x$ direct, $12 x$ online access to repository and eBook". (FA, 9 August 2021).

"More than 20 times". (DA, August 9, 2021).

“4 $x$ direct, $10 x$ online access". (FM, August 9, 2021).

The results of interviews with informants about visits to the integrated library of Poltekkes Jakarta III show that the average user visits are more than 20 visits a year. The results of the information about the use of OPAC in the search for information obtained the following results.

"Have you ever used OPAC services in seeking information?".

"Yes, every time you go to the library, you must use OPAC, because OPAC is very helpful in tracing information in the library". (BM. 7 August 2021).

"Once, OPAC was very helpful in tracing". (WF, August 8, 2021).

"Once, OPAC was the right choice when we were in the library about the information we needed." (GS, August 8, 2021).

"Yes, every time we go to the Jakarta III integrated library, the OPAC is opened, through OPAC we can find information in the library. (MC, August 8, 2021).

"Yes, once when searching for book titles". (FA, 9 August 2021).

“Ever (DA and FM, 9 August 2021).

The results of interviews with informants that OPAC is the right choice when searching for books in the library and other more specific information. OPAC is very helpful in finding information in the library.

Product Component. The results of product component information include the results of the achievement and usefulness of the OPAC web service program for users. The implementation of the OPAC web service program will be meaningful if the users feel the benefits. The following are the results of interviews with responses to the use of OPAC services at the Poltekkes Library, Ministry of Health, Jakarta III; "How is the current OPAC service responding?"

"For the sake of improvement, it still needs to be developed according to needs" (BM, August 7, 2021).

"Easy to search literature". (SR, August 8, 2021).

"Good enough, but when you enter there are no restrictions on who can enter to see the libraries in the Jakarta III Integrated Health Polytechnic Library" (WF, August 8, 2021).

"Easy to find information, especially library collections" (GS, 8 August 2021).

"Good, OPAC really helped me in finding the reference book I was looking for". (MC, August 8, 2021). 
"Pretty good" (FA, 9 August 2021).

"Never" (DA, August 9, 2021).

"Hopefully OPAC is better known and becomes a guideline". (FM, August 9, 2021).

Based on information from informants that the OPAC implemented in the Jakarta III Poltekkes Integrated Library greatly facilitates the search for information, especially library collections.

Results of interviews with informants about future OPAC inputs.

Like the following quote:

"What is the input for OPAC services in the future?".

"It is necessary to place reliable human resources, especially IT, for future development". (BM, August 7, 2021).

"We recommend that you upgrade to the latest one ". (SR, August 8, 2021).

"It needs to be improved to be upgraded so that it looks better, faster, and simpler" (WF, 8 August 2021).

"It needs to be adjusted to the development of Information and Communication Technology so that it looks attractive" (GS, 8 August 2021).

"OPAC can be developed and to help writers who want to secure their books in the library" (MC, August 8, 2021).

"Simple look needs a new look". (FA, 9 August 2021).

"Being a sophisticated application and better known by students in collaboration with BEM". (DA, August 9, 2021).

"The display has been upgraded according to the latest version (FM, 9 August 2021).

Added by M. Ichwan the application is quite good and can be run by librarians, but it needs an updated version to make it more attractive. Based on the information from the interview above, that the OPAC service program has been well achieved and its benefits can be felt for users, but the OPAC program needs to be developed, perfected with a more attractive appearance along with the development of the latest version.

In order to maintain the consistency of library services optimally, it is obtained information that the director monitors or supervises the implementation of the library. As the results of the following interview excerpts:

"What is the role of the director in monitoring and supervising the implementation of the library?".

"Regular supervision is carried out every month by holding coffee mornings, and gradually vicedirector III conducts coaching at any time". (BM, August 7, 2021).

Based on the results of interviews with informants that supervision is carried out periodically and in stages and provides guidance at any time. The supervision method is carried out with coffee morning in a relaxed atmosphere but does not reduce the real essence, namely the progress and benefit of the library as a forum for information, knowledge, recreation for users. Optimization of library services has the 
support of the leadership, but it is necessary to add more library staff, especially those with an educational background in library science.

\section{Discussion}

Context Component Evaluation.

The results of the evaluation of the context component show the suitability of policy support in the development of information technology-based libraries, especially regarding the library information retrieval service program through the application of the OPAC web. The role of the library is also in line with the vision and mission of Poltekkes Kemenkes Jakarta III in supporting the learning process. However, until now there is no written policy related to the development of information technology-based libraries with the implementation of the OPAC web which has been used since 2007. So that the evaluation of the context aspect can be presented as much as $70 \%$ in accordance with the policy. Meanwhile, $30 \%$ is not appropriate because there is no written policy.

The absence of a written policy regarding the implementation of the OPAC web service program may not be considered important, even though support for the budget for the procurement of applications and supplies for library staff has been carried out. Therefore, it is necessary to make written policies by the director as a reference in the implementation of information technology development at the Poltekkes Library of the Ministry of Health Jakarta III.

This policy is in line with the Regulation of the Head of the National Library of the Republic of Indonesia number 13 of 2017 concerning National Standards for Higher Education Libraries in attachment number 12. Information and communication technology that University Libraries utilize information and communication technology to realize the implementation and management of improving library performance and user needs.

As technology advances, Riggs (2010) the mission of libraries will not change with technology, but the way in which this mission is accomplished has changed dramatically. Facing increasingly complex challenges, libraries must be more introspective and have a strong commitment to responding to them. Building a commitment to bridge a change and turn a challenge into an opportunity for the library requires a dynamic and adaptive leadership to change. Therefore, a leader must be able to accept and adapt during uncertain changing situations to display the image of the library to the maximum level in achieving success in adapting to the dynamics of changes that occur.

The implementation of OPAC at Poltekkes Jakarta III is part of the representation of the Director's policy that supports the progress of the library. This was revealed in an in-depth interview with a BM informant on August 7, 2021, who stated that the directors and management were very supportive regarding the progress of the library by providing the facilities/budget needed for library development according to the priority scale. The OPAC web service program for the Jakarta Health Polytechnic Library III has been integrated with collection lending services. The application used in the OPAC service is SLIMS, which is a library software application that can be used to develop a library automation system (Aulia \& Asnghari, 2019).

Corbin in Hasugian (2003: 3) states that OPAC is a catalog containing bibliographical listings from the collection of one or several libraries, stored in recording media created online through a specified access point. OPAC is a database consisting of bibliographic records describing books and other materials owned by the library system, accessed through public terminals or workstations usually concentrated near reference desks to make it easier for users to ask for help from the librarian or librarian. Hendra (2014: 46) states that the manual transition to the online process, in addition to saving users time in searching, is also able to streamline the work of cataloging new library materials. Electronic 
catalogs such as OPAC are proven to be able to promote library collections so that the number of users is getting higher.

After a long time running, there are some perceived weaknesses in OPAC, so OPAC feels the need to re-evaluate its appearance which is still considered lacking. Responding to this does not have to be done immediately but must get support from the leadership to produce good output.

Leadership is a process of leaders creating a vision and interacting with each other and influencing each other to realize the vision. Leadership is a process of influencing a group to achieve certain goals. Leadership (leadership) has focused on terms of movement that tries to bring a group of people towards change towards a better and ideal. Therefore, it is conceivable that the function of a leader is to bring the organization into action.

It is not easy to create relationships within the leadership of an organization, especially a university library which has its own consequences. Laugu (2015) says that the intended consequence is that each line of relations has an ideological construction between actors who play their roles, both formally and informally. This ideological construction is manifested in the form of political propaganda, both openly and clandestinely, in influencing the behavior and actions of actors in organizational society which is then referred to as the representation of power. In conducting interactions, the leader must have their own criteria. Kumara stated that the criteria that must be possessed by a leader include the leader setting direction and speed, motivating the leader, setting goals, and determining policies. Leaders who have been able to meet the criteria well will be able to create leadership functions that are in line with expectations so that the resulting output is also good.

This research is in line with Rahmi's research (2017) in his research on the role of leaders in dealing with library trends at the Yogyakarta Regional Archives Library Office which states that the head of the Gunung Kidul KPAD library strongly implements the library's vision and mission. KPAD Gunung Kidul is not only a place to read and borrow collections but also a center for community empowerment. Currently, there are around 14 villages being fostered by the Gunung Kidul KPAD library and in 201710 villages will be added so that the number of villages to be fostered will be 24 villages.

Based on the description above, a written policy needs to be drawn up and determined by the director as the basis for implementing information and communication technology-based library development for library managers.

\section{Input Component Evaluation}

Evaluation of input components includes evaluation of the availability of collections, infrastructure, and library human resources.

Collection availability.

The availability of collections of the Poltekkes Kemenkes Jakarta III Library is felt to be quite complete and adequate both in terms of a variety of types and subjects. From the results of the interview, the information was felt to be useful to support the learning and research process for the community. The number of collections that reached 9,623 book titles with a total of 21,331 copies has been aligned with a classification system that makes it easy for users to find them. Collection searches can be traced via OPAC as well as retrieved directly on the shelf. Types and variety of collections include teaching materials, reference collections, serial publications, government publications, non-print collections, and reading materials for recreation such as literature. For the development of the collection so that it is right on target, it involves lecturers and students to provide input according to the needs of the user. The results of interviews with informants stated that the library has supported and played a role in realizing the tri dharma of higher education (education, research, and community service). From the description above, 
the evaluation of the availability of library collections is in accordance with the needs of users to support learning, research and community service programs for lecturers and students.

Availability of facilities and infrastructure

The Poltekkes Kemenkes Jakarta III Library already has facilities and infrastructure to support information service programs, especially in OPAC services. Two computers provided for the OPAC service can assist in finding information on book titles and the location of their collections on the shelves. Ease and speed in searching collections through OPAC supported by internet network through a good enough hotspot available $500 \mathrm{MB}$ in the library room. Currently, lecturers and students often visit the library to take advantage of the internet network. However, based on the researcher's observation that the number of computers still needs to be added and upgraded from the 17 available computers. Referring to the National Standard for College Libraries, about 30 computers are required for ICT-based services. Support for providing infrastructure for optimizing library services was conveyed by Deputy Director III that the Director and management are very supportive regarding the progress of the library by providing the facilities/budget needed for library development according to the priority scale" (BM, 7 August 2021). Thus, the provision of facilities and infrastructure needs to be improved, but still refers to the priority scale of needs.

Availability of library human resources

Evaluation of input to the HR Poltekkes Kemenkes Jakarta III Library is currently still lacking. The number of three librarians plus four administrative staff does not meet the National Standards for College Libraries. For the organization and management of a library with a collection of more than 9,000 with student members above 2,000, five librarians are needed and for every additional 500 students, 1 librarian is needed. The results of the document review of the Head of the Library Unit have proposed additional librarians but so far this has not been implemented. Lack of librarians affects the organization and processing of library material collections. The process of collecting collections, processing, maintaining until they are ready to be served requires sufficient energy and time. Library material processing activities include inventorying, classifying, cataloging, data entry and making library completeness, compiling catalog cards, return date slips, labels, barcode numbers so that it takes time and energy to process the library materials.

Activities to find the root of the problem and choose a solution and then implement improvements carried out by all librarians are usually supported by a development team that focuses on the purpose of the library. Total Quality Management (TQM) has many meanings, especially related to the improvement of library institutions by focusing on customers in the form of users which is achieved through grouping librarians and library staff at various levels in the library organizational structure. TQM is of the view that all librarians and library staff have an impact on the quality of service and the provision of information presented. The systems and processes of the library are of equal value to the information provided, the services provided, and their outputs.

For the users to feel satisfied, the university library works hard to ensure the quality of services and the provision of information in at least three respects, namely librarians, work programs and processes (facilities or facilities and infrastructure to support service activities, provision of IT-based information, learning facilities for users who are comfortable and so). Librarians must have strong competence in the field of libraries and their development. Work programs must be adapted to the needs of users, in particular supporting and supporting educational, research, and community service activities (Aziz, 2010). For the objectives and functions of the university library to be achieved properly in accordance with the predetermined targets, the library needs to be managed properly in accordance with the principles of the input aspect. Through good management, it is hoped that the library's objectives can be achieved, namely helping to increase knowledge, skills and values and attitudes of students and 
lecturers in improving the quality of graduates through the provision of library materials and other facilities such as reading rooms, assistance in finding scientific information and so on. This research is in line with research conducted by Muchlas (2014) evaluating collections, infrastructure, information technology at the Karanganyar Library in terms of SNI 7329.2009 shows that periodicals, information retrieval, textbooks, additions to collections are in accordance with the expected standards because of the existence of evaluation of the activities carried out for each activity carried out. From the evaluation of the input aspect, the availability of collections and the availability of facilities and infrastructure are good, but in terms of personnel, there is still a shortage of librarians, so that $80 \%$ can be a percentage.

\section{Process Component Evaluation}

The results showed that the evaluation of process components in library services at the Poltekkes Kemenkes Jakarta III Library using OPAC was good. This is shown by in-depth interviews with informants who said that the service was through OPAC. However, it still needs improvement along with the latest developments in information technology.

The Poltekkes Kemenkes Jakarta III Library has implemented the LISA (Library Information System - Automation) application since 2007. The LISA application is a web-based library information system to support library automation activities. This application is equipped with complete and integrated features in managing collections, library members, and admin managers. This makes it easier for borrowing circulation transactions and information retrieval for users. The Online Public Access Catalog feature, abbreviated as OPAC, is a search tool intended for users. The menu in the OPAC web consists of a simple search, a specific search with a display image title, author. Furthermore, for specific information, it contains additional details of other information such as calling number, ISBN/ISSN, language, publisher, year of publication. The Poltekkes Kemenkes Jakarta III Library provides 2 special computers for OPAC services for visitors. For how to use the OPAC, students and lecturers are given user guidance both individually and in groups. For new students, user guidance is carried out during PKKMB (Introduction to New Student Campus Life).

In addition, the Poltekkes Kemenkes Jakarta III Library has compiled guidelines and workflows such as Library Management Procedures and Library Service Work Instructions. The work instructions for library services include explaining how users can independently search for books they want to borrow through the OPAC. The results of the evaluation of this process aspect are supported by the results of interviews with informants about library visits and the use of OPAC by lecturers and students: The number of visits from interviews with informants shows an average of more than 20 visits a year. The results of the information about the use of OPAC in the search for information obtained the following results: have been used in searching for information and become the right choice when helping to search for information. The application of the OPAC web from 2007 is still using version 2 and at the time of the research, there was an upgrade process for the LISA application in May - November 2021. The updating process requires time to synchronize member and collection data so that it is up to the preparation of the final report of this research. the data updating process is still ongoing, so the latest OPAC web cannot be utilized.

OPAC is a technological development in library science, in addition to providing convenience for users, it is also easy for librarians to carry out cataloging activities. The purpose of OPAC according to Siregar (2004: 57) states that the transition from manual catalogs to online forms in addition to saving users a lot of time in searching is also able to increase the efficiency of cataloging new library materials. Electronic catalogs are also able to promote library collections so that their users are getting higher.

Tedd (2004) OPAC is an installed catalog system that can be accessed publicly and can be used by users to search the catalog database, to determine whether the library holds a particular work, to get information about its location, and if the catalog system is linked to a circulation system, the user can find out whether the library material being searched for is available in the library or is being borrowed. 
The quality of library services, in essence, cannot be formulated in absolute terms, because the formulation will depend on the extent of the perspective to be reached and who will formulate it. However, library-quality is often formulated as the end of an achievement that is carried out through a series of processes, both in short-term and long-term activities. In fact, the achievement process involves various other elements internally and externally.

A series of processes for achieving library-quality can be specified in three ways. First, the quality of library input; includes the skills of librarians, managers/heads of libraries, service, and administrative staff. Second, the quality of the process and context; the process of achieving library quality through service quality, collection quality, and effective quality and efficiency in the process of searching for information, as well as institutional and community support. Third, the quality of outcomes; excellent library services, satisfying and quality collections, and very supportive of the learning process of the academic community. Conceptually, all these elements interact and depend on one another. The three dimensions that determine library-quality are fundamentally a set of the library that reflects the quality of processes and outcomes. Therefore, the logical sequence of the process of achieving library quality is the presence of inputs that have mental readiness, the existence of a service process that is supported and adapted to the needs of users, and produces quality outcomes as a product of the previous series of processes.

As a tool in OPAC services and searches that contain all information on physical conditions discussed in books or other media that are clearly known. User service through OPAC is important because the performance of the information system, economy, control, and efficiency and service is quite good. The application of OPAC is important as long as it fulfills several indicators in its application, namely: (1) content, namely discussing the contents of an information system; (2) accuracy, namely showing the accuracy of the information system; (3) form (format), namely judging in terms of the appearance of the information system; (4) ease of use, namely the ease of using the information system; (5) timelines, namely measuring the speed and accuracy of providing information (Doll \& Torkzadeh in Kamala, 2018). This research is in line with Maisaroh's research (2018) that the use of OPAC in the KOHA automation system at the Surakarta Muhammadiyah Library with the Acceptance Model (ATM) technology method is in the total good category. Based on the description above, the percentage of evaluation of the input aspect has been reached $100 \%$.

\section{Product Component Evaluation}

The results of the study show that the achievement of library services using OPAC is good. This can be seen from the use of OPAC by informants and secondary data from the Jakarta III Health Polytechnic library. According to the informant, the achievement of OPAC services is quite good, but when entering there are no restrictions on who can enter to view the libraries in the Jakarta III Health Polytechnic Integrated Library. assist in searching for information in the library. In carrying out library service activities, there must be several main elements, including library service facilities, library materials that can be provided, users in need, and service officers, and the use of information technology in libraries such as OPAC. These elements must be the main consideration for libraries that want to provide user services. Service facilities, such as collection rooms, reading rooms, and search facilities must of course be available for users to use. Various types of library materials are in accordance with the target audience and users who need information, as well as officers who are ready to serve and assist users in finding information (Rahayu, 2017).

Because library service activities interact directly with users, users can directly assess whether the organization of the library is good or bad based on user satisfaction with the services provided. Thus, it can be said that the image and success of the library in carrying out its functions is determined by the performance of library services to its users. In this regard, many are of the opinion that library services are the spearhead of library administration. 
In terms of the interests of the library, the purpose of organizing library services, in general, is so that the library materials provided by the library can be utilized optimally by the users. It is very meaningless if library materials that are collected, processed, and neatly arranged in the library cannot be utilized optimally by the users. If it is related to the existence of the Jakarta Poltekkes III library service, then with all aspects related to all activities carried out to fulfill information for users, input, process, and output in the evaluation of OPAC-based service programs simultaneously or continuously in support of the achievement of the institution's mission. Input is input for the system to function. Evaluation at the initial stage of the program aims to ensure that the plans to be implemented are in accordance with the problems found which include existing resources, funds, manpower, facilities, and infrastructure. The input values have an impact on program implementation and program achievement targets. The input value obtained is less so that the process and output achievements are not in accordance with what is desired. Processes are needed to convert inputs into planned results (outputs). Process evaluation aims to determine whether the program is being implemented according to the initial plan. Output (output) is the result of the process. The evaluation shows whether a program has influenced behavior as planned. Output can be seen from changes in knowledge, attitudes, and behavior of the target (Wibowo, 2017).

Based on the nature of library services, with a user-oriented orientation, library services are organized with the aim of helping to meet the information needs of users in a precise and accurate manner, namely through the provision of library materials and the provision of search facilities. From this effort, it is hoped that user satisfaction with the information services provided can be achieved. This is what can determine the good and bad image of the library, namely user satisfaction with library services because if the user is satisfied, the user will be encouraged to return to using the library services. This research is in line with research conducted by Ghazali (2017) evaluating the effectiveness of the information retrieval system which can be measured using a precision value, it can be concluded from the results of the evaluation that has been carried out, namely in measuring the effectiveness of the OPAC information retrieval system at the UIN Sunan Kalijaga Yogyakarta library using the precision value. which shows that the evaluation process cannot be separated from the policy to be carried out.

Evaluation of the usefulness and impact of the OPAC service program on users The results showed that the impact of OPAC on user usability was good. This can be obtained from information from informants through in-depth interviews that need to be adjusted to the development of Information and Communication Technology so that it looks attractive.

Poltekkes Jakarta III Library is a library that has implemented library automation. In the process of retrieving information, the Jakarta III Poltekkes library uses the OPAC (Online Public Access Catalog) application. In addition, the OPAC (Online Public Access Catalog) application for the Poltekkes Jakarta III library offers access or information search services online or locally (using the campus network) which makes it easier for users or users to search for collections in the Poltekkes Jakarta III library. In this study, the authors chose the Poltekkes Jakarta III library as a place of research and the application of OPAC (Online Public Access Catalog) as the research subject.

First, the Poltekkes Jakarta III library has implemented library automation system technology on the services in the library. Second, the Poltekkes Jakarta III library is a university library that hopes for category " $\mathrm{A}$ " accreditation, in which the accreditation assessment is carried out by reviewing, among others: service feasibility, available reference feasibility, human resources, and data suitability with realities in the field. With this "A" category accreditation label, the Jakarta III Poltekkes library must further improve its services, one of which is the OP $A C$ application information retrieval system (Online Public Access Catalog).

Third, compared to the OPAC (Online Public Access Catalog) application for other university libraries that provide two search boxes, namely simple search and advanced search, while the OPAC (Online Public Access Catalog) application for the Jakarta III Health Polytechnic Library only provides one search box. 
The usefulness of OPAC services at Poltekkes Jakarta III for users is very much felt by users who feel that OPAC is very helpful in finding book references. In addition, the evaluation of the retrieval system on the OPAC (Online Public Access Catalog) can be done based on Claverdon's theory, namely (Chowdhury, 2010: 284): Recall, namely the ability of the system to display all information objects that were called. Precision, which is the ability of the system to display only objects/relevant information from the called object. Time lag, which is the average interval between the search time and the time to get information. The effort, namely the intellectual and physical aspects to get information. Form of presentation of search output, namely the ability of the system to affect the user's ability to use the information found. Coverage of collection, namely the suitability of the information with the object being sought.

In evaluating the impact of the OPAC service program on users, the existing features can be developed again with the simplest possible appearance. This can be seen from the informant who said that the display needs to be upgraded according to the latest version. From it was posted to users in 2007 until this year, the OPAC feature has never been upgraded.

Gradual developments in bibliographic standards, tremendous advances in computer and communication technology, growth in the utility of bibliography and networking have led to the development and design of the Online Public Access Catalog (Babu and O'Brien, 2000). This opinion shows that OPAC (Online Public Access Catalog) as an information retrieval system continues to be developed in terms of design and bibliographic features, along with this fact it is important to evaluate the OPAC system so that its functional capabilities are better and user-friendly. Evaluation is carried out to determine the performance of a system made and to provide an assessment of the system. Evaluation is very useful so that the organization knows where the level of strength and weakness of the system is.

Remenyi and Sherwood in Grembergen (2010: 59) argue that evaluation is a series of activities that combine understanding, measurement, and assessment. It is a deliberate process and aims to determine the value or share of a situation. It can also relate to determining the value of an object. This opinion reinforces the reason for the necessity of evaluating, namely, to determine the value and position of system use.

The first reason shows that the online catalog (OPAC) is the first point of contact for library users, therefore libraries must provide a system that is designed with a good interface so that the features needed by users are met through the library system. The second reason states that the evaluation will increase the usability of the system so that users will feel satisfied and will return to using the library system, this means that by evaluating the weaknesses in the system to be improved. The third reason states that the collection resources owned by the library will be wasted if the system makes it difficult for users to search for collections. A good system should be evaluated as it affects the performance of the library. The OPAC should aid users with self-constructed help messages or direct staff assistance or even both, to promote optimal use of the OPAC. The more assistance the system can provide to users, the less likely the user will fail when interacting with the OPAC, (Madhusudhan \& Aggarwal, 2014).

This research is in line with Sinaga's (2018) research. An important subject search assistance feature is to provide, namely by creating a subject header file in the OPAC system that is related to the availability of an online classification list in the system and a subject vocabulary list. Based on the description above, the percentage of product aspect evaluation is achieved and has $100 \%$ benefit for users.

\section{Conclusion}

Evaluation of the Context Component has complied with the policy, achieved $70 \%$. The implementation of the OPAC web has been implemented since 2007. There is funding support and 
provision for library human resources in the library computerized system. While the $30 \%$ shortfall is that there is no written policy for the application of information technology in OPAC web services. Written policies are needed as a reference for library managers in carrying out their duties. The reason for the absence of a written policy may be that it is not considered important or has received less attention.

Evaluation of Input Components achieved 80\%. Availability of an adequate collection of the number, type, and variety of subjects. Availability of facilities and infrastructure to support the OPAC web service program. While the shortage of $20 \%$ is a shortage of librarians who do not meet the standards. The shortage of manpower is sought through the recruitment of civil servants in 2021 .

Process Component Evaluation reached 100\%. In the OPAC web service process, the user does not experience difficulties in accessing but instead feels the ease and speed of getting the information needed. The Poltekkes Kemenkes Jakarta III library has a library management procedure with work instructions for library services. In addition, librarians provide ongoing user guidance to the academic community.

Product Component Evaluation reached 100\%. This is due to the achievement and usefulness of the OPAC web service program for users. These achievements and benefits need to be maintained and improved in line with the latest developments in information technology. The implementation of the OPAC web access service indirectly has an impact on increasing online visits to the library web http://perlibatan.poltekkesjakarta3.ac.id

\section{Bibliography}

Aulia \& Asnghari (2019). OPAC Services as an Efficient Information provider. Tinandaru Journal 2019 Vol. 3. Number. 2. pp. 45-55.

Aziz (2010). Strategy to Improve Quality in College Libraries. Journal of Library Vision Vol. 12 No. 2 pp.49-58.

Babu, B Ramesh and Ann O'Brien. 2000. Web OPAC interfaces: an overview. The Electronic Library. Vol 18, no 5.

Donald E. Riggs (2010) “The Crisis and Opportunities in Library leadership”, Mark D. Winston (ed.) Leadership in the Library and Information Science Professions; Theory and Practice, Canada: The Hawort Information Press.

Ghazali (2017). Evaluation of the System for Retrieval in Opac Formation (Online Public Access Catalog) at the Library of Poltekkes Jakarta III (UIN) Sunan Kalijaga Yogyakarta. Journal of Alwatzikhoebillah (Islamic Studies, Education, Economics, and Humanities). Vol. III No. January 5th. Pp.99-111.

Hasugian (2013). Library Catalog from Manual Catalog to Online Catalog. Medan: University of North Sumatra.

Kemala (2018). Effectiveness of the Online Public Access Catalog as an Information Retrieval System at the Denpasar Health Polytechnic Integrated Library. D3 Scientific Journal Library Vol.1 No.1.pp.1-8.

Kumara (2015) Leadership in Libraries: a Focus on Ethnic-Minority. Libraries, United Kingdom: Chandos Publishing.

Laugu, N. (2015). Representative Power in Library Management. Yogyakarta: Gapernus Press. 
Maisaroh (2018). Evaluation of the Use of the Online Access Catalog (OPAC) in the Koha Library Information System at the Surakarta Muhammadiyah Library. Thesis of State University of Sunan Kalijaga Yogyakarta.

Madhusudhan, Margam and Shalini Aggarwal. 2014. Online Public Access. Catalogs of Selected University Libraries in Delhi: An Evaluative Study. Vol 7, no 1.

Rahayu (2018). Library Services. Jakarta, Jaya Utama.

Sinaga (2018). Evaluation of the Online Public Access Catalog Features of the Medan State University Library Using the Cherry Checklist.

Wibowo, 2017. Performance Management. Jakarta, Rineka Cipta.

\section{Copyrights}

Copyright for this article is retained by the author(s), with first publication rights granted to the journal.

This is an open-access article distributed under the terms and conditions of the Creative Commons Attribution license (http://creativecommons.org/licenses/by/4.0/). 